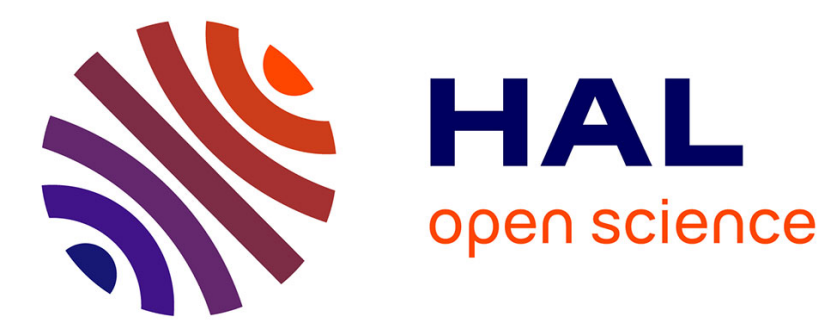

\title{
Collective designing and sharing of open educational resources: a study of the French CARTOUN platform
} Nolwenn Quéré

\section{To cite this version:}

Nolwenn Quéré. Collective designing and sharing of open educational resources: a study of the French CARTOUN platform. EuroCALL, Aug 2017, Southampton, United Kingdom. 10.14705/rpnet.2017.eurocall2017.723 . hal-02422168

\section{HAL Id: hal-02422168 \\ https://hal.science/hal-02422168}

Submitted on 20 Dec 2019

HAL is a multi-disciplinary open access archive for the deposit and dissemination of scientific research documents, whether they are published or not. The documents may come from teaching and research institutions in France or abroad, or from public or private research centers.
L'archive ouverte pluridisciplinaire HAL, est destinée au dépôt et à la diffusion de documents scientifiques de niveau recherche, publiés ou non, émanant des établissements d'enseignement et de recherche français ou étrangers, des laboratoires publics ou privés. 


\title{
Collective designing and sharing of open educational resources: a study of the French CARTOUN platform
}

\author{
Nolwenn Quere ${ }^{1}$
}

\begin{abstract}
Designing and sharing Open Educational Resources (OERs) requires teachers to develop new competences, in particular with digital resources. In this paper, the case of a language resource production group is introduced. Due to the centrality of the OERs in their collective activity, I show that the documents they produce are essential to the group's work. The theoretical framework of the Documentational Approach (DA) is used in order to analyse their design of resources, the development of their resource system, and how it is linked with professional development.
\end{abstract}

Keywords : OER, collective teacher work, professional development.

\section{Introduction}

The availability of OERs has introduced drastic changes in education (European Commission, 2013) regarding both the nature of resources and teachers' interactions with such resources, as users as well as designers. Designing and using an OER, in particular OERs like lesson plans incorporating the use of software, requires new competences. Using OERs is likely to contribute to teachers' professional development and more specifically the development of new practices with digital resources. Collective teacher work can support this integration. The example of lesson studies in Japan (Miyakawa \& Winsløw, 2009) highlights the benefits of collective work (construction of a lesson) for professional development. In this paper, the aim is to analyse how collective designing of OERs, and exchanging such resources on a distant platform can contribute to teachers' professional development. The elements presented are the results of an ongoing study on language teachers; members of a group supported by the regional local authorities.

1. Université de Bretagne Occidentale, Brest, France; nol.quere@gmail.com

How to cite this article: Quere, N. (2017). Collective designing and sharing of open educational resources: a study of the French CARTOUN platform. In K. Borthwick, L. Bradley \& S. Thouësny (Eds), CALL in a climate of change: adapting to turbulent global conditions - short papers from EUROCALL 2017 (pp. 260-264). Research-publishing.net. https://doi.org/10.14705/rpnet.2017.eurocall2017.723 


\section{Theoretical framework}

To conduct the analysis, the theoretical framework of the DA (Gueudet \& Trouche, 2009 ) is used. This approach has been developed to study the interactions between teachers and resources; when using these resources, teachers develop schemes of use (Vergnaud, 1998). The mixed entity composed of resources and schemes of use is called a document.

The scheme is a stable structure associated with an aim of the activity, comprising several components, in particular Operational Invariants (OIs). The OIs are divided in theorem-in-action, considered as true by the subject when he/she acts, or conceptin-action, and considered as relevant to categorise and select information. The OIs are interpreted as professional knowledge.

Gueudet and Trouche (2009) argue that resources influence the teacher's activity (instrumentation, i.e. the modification of the subject's schemes of action). The teacher acts on his/her resources in return by adapting them (instrumentalisation, i.e. the creation of new functions of the artifact by the subject) during documentational genesis to generate a document. Teachers develop resources and document systems. Their professional development is directly linked with the development of these systems. In this paper, the following research questions are addressed:

- Do the members' group really integrate the resources of the community in their own resources' system?

- Do their participation in the group make their OIs evolve?

\section{Data collection methods and analysis}

The group of pedagogical integration of the uses of digital technology (GIPUN) is the name of the collective followed. The group is composed of seven language teachers (four English, two Spanish, and one German teacher). The collective concentrates part of its activity on designing resources for a platform named CARTOUN. The latter offers a collaborative geo-positioning service listing pedagogical activities designed and uploaded by teachers and for teachers in Brittany.

The data introduced is extracted from the annual meeting of the group. They use a mailing list during the rest of the year for their exchanges. The study is based on a qualitative methodology. Observed, in particular, is how resources are 
designed by the members. I do not interact with the members during their work. The audio of the exchanges is recorded and reduced into a synopsis. From there some specific episodes are selected which can illustrate the work of the members on their documents. Finally, these episodes are transcribed in order to identify OIs in members' speeches.

\section{Results and discussion}

\subsection{Introduction of a new resource into the community resources' system}

The group has an activity devoted to technological watch focussed on digital resources. This activity leads the members to discover and experiment with new resources. During the meeting, the group facilitator and English teacher (with 14 years teaching experience) presents the BRNE (digital library for schools). This database currently offers resources in English and German to help teachers set up differentiated pathways in class. Following a presentation, the group facilitator asks the members to test this new resource and to provide some feedback by producing an activity document ${ }^{2}$ on CARTOUN.

To conduct the analysis, elements in the members' accounts on the possibilities of compatibility of the BRNE with their resources are identified. The time constraint associated with the discovery of new resources is mentioned in the discussion by one of the members. A member explains about her work that "it's more time consuming when I use an unfamiliar digital tool I need to test [...]. I needed at least 2 hours of personal involvement". From this extract, the following OI (theoremin-action) is inferred: "discovering a new digital tool takes time". Another member highlights her interest in the resource as it allows differentiation: "It's good to help those who do not get there, it always saddens me to see those who are bored". The following OIs are defined in this regard: "the weaker students are bored in class if something specific is not prepared for them". These examples suggest that the BRNE is a resource whose appropriation is time-consuming and facilitates the implementation of differentiation in the classroom. These first elements do not seem to contradict the members' OIs. Therefore, I assume that the resource can be introduced into an individual member's resource system.

2. To share their OER online, the teachers have to fill a form with specific items (class, subject, hardware/software). 


\subsection{Discussing new aims: a way to help Ols evolve}

After having worked on the design of resources, the members wish to support their management in order to favour its appropriation and dissemination. To do this, they move towards setting up what they call 'functional help'. When a teacher designs the document, he/she inputs the information he/she judges necessary for the implementation of the session/sequence. This suggests that a teacher who is not a member of the group but only a user of the documents must have a certain amount of knowledge, notably on technological resources, to master this resource. However, the teachers' knowledge outside the community is not necessarily the same as the members' group knowledge. That's why the latter want to facilitate the users' appropriation of these resources. Another English teacher, with teaching experience of more than seven years, points out this difficulty and starts the discussion. She has already animated webinars ${ }^{3}$. Also, she is familiar with questions on ownership, explaining that "doing basic training on Audacity, Plickers, and Windows Movie Maker would not be a bad idea". She also says that it is "crucial that those who present their successful project also discuss their difficulties". From these examples, two OIs are inferred. The first is that it is necessary to ensure basic knowledge of softwares. The second highlights that the difficulties encountered in the design and/or implementation must be shared. It can be assumed that sharing this knowledge will have two effects on the teachers' work. Firstly, the discussion about resources should lead to transformation/modification of the document forms (instrumentalisation) by the members trying to incorporate these new points. Secondly, in these exchanges, the teacher brings elements of her professional knowledge that could change the members' interactions with their resources by modifying their design work. She is likely to influence the development of the document systems of all members.

\section{Conclusion}

In this paper the aim was to show how collective work with OERs can contribute to evolutions in the resources and document systems of teachers and to their professional development. Analysing the data collected, this study shows that a new resource is integrated into the resource's system if this resource is compatible with one of the teacher's OIs. Also, OIs, as elements of knowledge, are likely to evolve during the discussion between members in a collective. Teachers' OIs will be studied over a long period in order to analyse the central role of the

3. Webinar: various types of online collaborative services and peer-level web meetings. 
documents in the resources' system of the community. These documents allow the double process of instrumentation-instrumentalisation that supports professional development (Gueudet \& Trouche, 2009).

\section{Acknowledgements}

I would like to thank the group of teachers who allowed me to follow them, and the Brittany region for funding my research.

\section{References}

European Commission (2013). Analysis and mapping of innovative teaching and learning for all through new technologies and open educational resources in Europe. http://eur-lex.europa. eu/LexUriServ/LexUriServ.do?uri=SWD:2013:0341:FIN:EN:PDF

Gueudet, G., \& Trouche, L. (2009). Towards new documentary systems for mathematics teachers. Educational Studies in Mathematics, 71(3), 199-218. https://doi.org/10.1007/s10649-0089159-8

Miyakawa, T., \& Winsløw, C. (2009). Un dispositif japonais pour le travail en équipe d'enseignants: étude collective d'une leçon. Education \& Didactique, 3(1), 77-90. https:// doi.org/10.4000/educationdidactique.420

Vergnaud, G. (1998). Toward a cognitive theory of practice. In A. Sierpinska \& J. Kilpatrick (Eds), Mathematics education as a research domain: a search for identity (pp. 227-241). Kluwer Academic Publisher. 


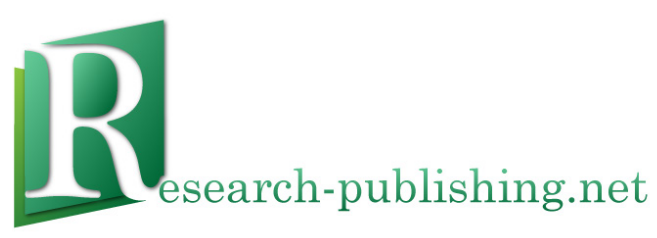

Published by Research-publishing.net, not-for-profit association Contact: info@research-publishing.net

(C) 2017 by Editors (collective work)

(C) 2017 by Authors (individual work)

CALL in a climate of change: adapting to turbulent global conditions - short papers from EUROCALL 2017 Edited by Kate Borthwick, Linda Bradley, and Sylvie Thouësny

Rights: This volume is published under the Attribution-NonCommercial-NoDerivatives International (CC BY-NC-ND) licence; individual articles may have a different licence. Under the CC BY-NC-ND licence, the volume is freely available online (https://doi.org/10.14705/rpnet.2017.eurocall2017.9782490057047) for anybody to read, download, copy, and redistribute provided that the author(s), editorial team, and publisher are properly cited. Commercial use and derivative works are, however, not permitted.

Disclaimer: Research-publishing.net does not take any responsibility for the content of the pages written by the authors of this book. The authors have recognised that the work described was not published before, or that it was not under consideration for publication elsewhere. While the information in this book are believed to be true and accurate on the date of its going to press, neither the editorial team, nor the publisher can accept any legal responsibility for any errors or omissions that may be made. The publisher makes no warranty, expressed or implied, with respect to the material contained herein. While Research-publishing.net is committed to publishing works of integrity, the words are the authors' alone.

Trademark notice: product or corporate names may be trademarks or registered trademarks, and are used only for identification and explanation without intent to infringe.

Copyrighted material: every effort has been made by the editorial team to trace copyright holders and to obtain their permission for the use of copyrighted material in this book. In the event of errors or omissions, please notify the publisher of any corrections that will need to be incorporated in future editions of this book.

Typeset by Research-publishing.net

Cover design based on (C) Josef Brett's, Multimedia Developer, Digital Learning, http://www.eurocall2017.uk/, reproduced with kind permissions from the copyright holder.

Cover layout by (C) Raphaël Savina (raphael@savina.net)

Photo "frog” on cover by (C) Raphaël Savina (raphael@savina.net)

Fonts used are licensed under a SIL Open Font License

ISBN13: 978-2-490057-04-7 (Ebook, PDF, colour)

ISBN13: 978-2-490057-05-4 (Ebook, EPUB, colour)

ISBN13: 978-2-490057-03-0 (Paperback - Print on demand, black and white)

Print on demand technology is a high-quality, innovative and ecological printing method; with which the book is never 'out of stock' or 'out of print'.

British Library Cataloguing-in-Publication Data.

A cataloguing record for this book is available from the British Library.

Legal deposit: Bibliothèque Nationale de France - Dépôt légal: décembre 2017. 